IRSH 52 (2007), pp. I-34 DOI: I0.10I7/S0020859006002768

(C) 2007 Internationaal Instituut voor Sociale Geschiedenis

\title{
Privileging the Machines: American Engineers, Indentured Chinese and White Workers in South Africa’s Deep-Level Gold Mines, I902-1907*
}

\author{
J OHN HIG G IN S O N
}

Summary: Economists and historians have identified the period between i 870 and I9I4 as one marked by the movement of capital and labor across the globe at unprecedented speed. The accompanying spread of the gold standard and industrial techniques contained volatile and ambiguous implications for workers everywhere. Industrial engineers made new machinery and industrial techniques the measure of human effort. The plight of workers in South Africa's deep-level gold mines in the era following the Anglo-Boer War of I 899- 1902 provides a powerful example of just how lethal the new benchmarks of human effort could be. When by I 904 close to 50,000 Africans refused to return to the mines, mining policy began to coalesce around solving the "labor shortage" problem and dramatically reducing working costs. Engineers, especially American engineers, rapidly gained the confidence of the companies that had made large investments in the deep-level mines of the Far East Rand by bringing more than 60,000 indentured Chinese workers to the mines to make up for the postwar shortfall in unskilled labor in late 1904. But the dangerous working conditions that drove African workers away from many of the deep-level mines persisted. Three years later, in 1907 , their persistence provoked a bitter strike by white drill-men.

\section{INTRODUCTION: IMPERIALISM AND ITS DISCONTENTS}

To the several cabinets the several political establishments of the world are clothes-lines; and a large part of the official duty of these cabinets is to keep an eye on each other's wash and grab what they can of it as opportunity offers. All the territorial possessions of all the political establishments of the earth including America, of course - consist of pilferings from other people's wash. Mark Twain, c.I $895^{\mathrm{I}}$

The money that will be required here [in South Africa] is startling in its amounts, and with the apathy which the world has been led to feel toward us, I cannot but

* The author would like to thank Carol Archibald, Roderick Aya, Joye Bowman, Sakhela Buhlungu, Malaika Chehab, Greg Cuthbertson, Michael Mcethe, David Montgomery, Rosanne Rutten, Keith Shear, Christoph Strobel, Charles Tilly, Charles van Onselen, and two anonymous readers for their helpful observations and criticisms. The remaining faults are my own.

I. Mark Twain, Following the Equator, II (Hollcong, PA, 200I), p. 298. 
feel that organized capital will have great opportunities [...].

W.L. Honnold to Robert Goering, 25 July $1904^{2}$

[...] I don't think that Robinson Crusoe was much of an engineer until he had

Friday to help him; [...].

$$
\text { R.W. Henry, a colleague of W.L. Honnold, c.19043 }
$$

Markets, especially labor markets, give off ambiguous signals about what is appropriate economic behavior. Albert O. Hirschmann called this phenomenon "the passions and the interests". ${ }^{4}$ Historians and economists now recognize that the modern roots of this ambiguity can be found in the dramatic mobility of capital and labor between I 870 and I9I 4.5 Not until the present era have either been so mobile. ${ }^{6}$

Industrial capitalism drew the world together as never before during this period. The new proximity contained immense implications for the laboring masses of the industrial and colonial countries. Few of them were beneficent. ${ }^{7}$ Hundreds of thousands of Africans, Amerindians, Chinese, Indians, and Pacific Islanders were hauled off to labor on sugar plantations in the Caribbean, Peru, South Africa, Mauritius, and Hawaii. They built railroads in places as removed from each other as California and Uganda. They dug precious and base metals and coal out of the earth in Indonesia, Malaya, South Africa, China, and Brazil. None were freely contracted. Their time of laboring was something just short of bondage. The industrial powers, including Japan, created a climate in which the global pool of non-European labor became appallingly cheap and

2. William Lincoln Honnold Papers, Honnold Library, Claremont University Center, Claremont, CA [henceforth WLHP], letter book B.

3. R.W. Raymond, "The Modern Engineer", Engineering and Mining Journal [henceforth EMJ], I 8 February 1904, p. 270.

4. Joseph Schumpeter, History of Economic Analysis (New York, I986), pp. 617-61 8, 622-624; Ronald Dworkin, Law's Empire (Cambridge, MA, 1986), p. 277; Albert O. Hirschmann, The Passions and the Interests (Princeton, NJ, 1981), pp. 102-105.

5. See P. Pic, "Les Enseignments de quelques grèves recentes”, Revue d'économie politique, 26 (I9I 2), pp. I-3; see also Carl P. Parrini and Martin J. Sklar, "New Thinking about the Market, I 896-1904: Some American Economists on Investment and the Theory of Surplus Capital", Journal of Economic History, 43 (1983), pp. 559-569; Charles Sabel and Jonathan Zeitlin, "Historical Alternatives to Mass Production: Politicas, Markets and Technology in Nineteenth Century Industrialization”, Past and Present, I08 (1985), pp. I33-176.

6. David W. Galenson, "The Rise and Fall of Indentured Servitude in the Americas", Journal of Economic History, 44 (1984), pp. I-26; W. Arthur Lewis, The Development of the International Economic Order (Princeton, NJ, 1978), pp. 14-26; David Northrup, Indentured Labor in the Age of Imperialism (New York, 1995), pp. 4-14; Joseph E. Stiglitz, Globalization and its Discontents (New York, 2003), pp. 214-222.

7. For a more sanguine view of these experiences see: David Landes, The Wealth and Poverty of Nations: Why Some Are So Rich and Some So Poor (New York, 1998), pp. 2-9; see also Akira Iriye, "Beyond Imperialism: The New Internationalism", http:hnn.us/articles/1362 5.html; reprinted from Daedalus (Spring, 2005), pp. 2, 3. 
apparently unlimited. ${ }^{8}$ Military enclosure of most of the non-Western world and the subsequent demand that the colonies pay for themselves hastened the advent of a second servitude based on the indentured labor of non-white peoples from the colonial and semi-colonial countries. This second servitude bore a chilling resemblance to modern slavery. ${ }^{9}$ It gave anyone who cared to notice good reason to be attentive to the dark side of progress.

American engineers and technical experts were called upon to assist in the extraction of wealth from colonies around the world. They figured importantly in disseminating new industrial techniques and in attempting to order and reorganize the relations between non-white workers and industrial enterprises. They played an especially important role in opening many of the new deep-level gold mines in South Africa after I $895 .{ }^{10}$ The collapse of global money and financial markets, which was a result of the financial uncertainty surrounding long-term exploitation of South Africa's deep-level gold mines, encouraged a greater dependence on American engineers. ${ }^{\text {II }}$ Shula Marks and Stanley Trapido observed:

By I 895 at least half of the new gold mines were managed by Americans and the chief engineers of both the Wernher-Beit group and Rhodes's Consolidated Gold Fields were Americans. These engineers had not only wide experience in the American West, Latin America and Asia, but contemporaries saw them as a "new industrial intelligentsia" standing between capital and labour and peculiarly fitted to resolve the nation's social conflicts. ${ }^{\text {I2 }}$

8. See Kay Saunders (ed.), Indentured Labor in the British Empire, I834-1920 (London, 1984); Walton Look Lai, Indentured Labor, Caribbean Sugar: Chinese and Indian Migration to the British West Indies, I838-1918 (Baltimore, MD, I993); Peter Richardson, Chinese Mine Labour in the Transvaal (London, 1982); Gary Kynoch, "Your Petitioners are in Mortal Terror: The Violent World of Chinese Workers in South Africa, 1904-1910”, Journal of Southern African Studies, 3 I (2005), pp. 53 I-546; Northrup, Indenture Labor in the Age of Imperialism, pp. I 839.

9. Sidney Mintz, Sweetness and Power: The Place of Sugar in Modern History (New York, 1985), 71; see also David Montgomery, "Workers' Movements and Imperialism: From Berlin (I884) to Baku (1920)", Workers of the World Colloquium Series, Yale University, New Haven, CT, 28 September 2005 , pp. I-28.

ı. See James Livingston, "The Social Analysis of Economic History and Theory: Conjectures on late Nineteenth Century American Development”, American Historical Review, 92 (1987), pp. 76-78; see also D.A. Wells, Recent Economic Changes (New York, I890), pp. 408-4I 5 .

I I. On 4 July I 896, the Engineering and Mining Journal correspondent in Paris filed this report, "Perhaps the most marked feature of our stock market this week has been the continued revival of interest in Southern African stocks. The better report of gold production on the Witwatersrand in May, which has just been received, has helped in this, and people are beginning to hope that the political operators of London and Johannesburg have decided to let the matter alone"; see EMJ, I August I896; see also R.V. Kubicek, Economic Imperialism in Theory and Practice (Durham, NC, 1979), pp. 330-350; Schumpeter, History of Economic Analysis, pp. $766-767$.

I2. Shula Marks and Stanley Trapido, "Lord Milner and the South African State", History Workshop, Spring 1979, p. 6I; see also Twain, Following the Equator, II, pp. 354-355. 
American engineers made their way into courts, schools, government commissions, factories, and prisons as expert witnesses and spokesmen for capital in South Africa. They became agents of modern technology as well as corporate capital. ${ }^{\mathrm{I}}$ American engineers in South Africa also took the lead in attempting to destroy the tactical power of the most privileged strata of white mineworkers by generalizing the application of the MacArthur-Forrest cyanide leaching method for gold ore and by altering the work routine in the deep-level mines. The latter alteration was effected by adding tens of thousands of indentured Chinese workers to the largely African unskilled workforce between 1904 and 1907. In so doing, they stood in for the "passions and interests" of the mine owners and provided a textbook illustration of Thorstein Veblen's claims that engineers, by virtue of their technical expertise, had become industrial leaders almost a generation before the appearance of Engineers and the Price System. ${ }^{\mathrm{I}}$

What made the efforts of the American engineers and their allies even more startling was that they embarked upon them during the tumultuous depression of 1906-1908 and did not relent until the global recession of I922 and the intensely violent but failed general strike and rebellion of South Africa's white mineworkers. ${ }^{\text {Is }}$ A sharp debate also ensued about whether shareholders or the entrepreneurs themselves should assume the greatest amount of risk in increasing the number of deep-level gold mines in operation. ${ }^{16}$ The intervention of the "two penny-ha" penny people" was nothing short of ludicrous for most of the mine owners and mining executives. ${ }^{17}$ After 1904, however, the mine owners withdrew from direct intervention in the industry once investment groups transformed their institutional connection to the mines. ${ }^{18}$

I 3. See David F. Noble, America by Design (New York, 1977), pp. xxii-xxv.

I4. See Maryna Fraser and Alan Jeeves (eds), All That Glittered: Selected Correspondence of Lionel Phillips, I890-1924 (New York, 1977), p. I 82; Lionel Phillips, Transvaal Problems: Some Notes on Current Politics (London, 1905), pp. 35-48; Alan Jeeves, Migrant Labour in South Africa's Mining Economy (Kingston [etc.], 1985), pp. 60-62; Thorstein Veblen, Engineers and the Price System (New York, I92 I), pp. 35-48.

I 5. See Jeremy Krikler, White Rising: The 1922 Insurrection and Racial Killings in South Africa (New York [etc.], 2005), pp. 35-38; see also idem, "The Commandos: The Army of White Labour in South Africa", Past and Present, I63 (1999), pp. 203-244.

I6. See Charles van Onselen, "The World that the Mine Owners Made: Social Themes in the Economic Transformation of the Witwatersrand, I886-1914", in idem, Studies in the Social and Economic History of the Witwatersrand I886-1914, I (Johannesburg, I982), pp. I-43; see also Charles Harvey and Jon Press, "Overseas Investment and the Professional Advance of British Metal Mining Engineers, I8 5 I-I9I4”, Economic History Review, 42 (I989), p. 8 I.

17. Fraser and Jeeves, All That Glittered, pp. 178-182.

I8. See Peter Richardson and Jean-Jacques van Helten, "The Development of the South African Gold Mining Industry, I895-I9I 8”, Economic History Review, 37 (I984), pp. 330-342; see also Charles Harvey and Jon Press, "The City and International Mining, 1870-1914", Business History, 32 (1990), pp. 99-I I9. 
Professional engineers began to supplant the more swashbuckling entrepreneurs and managers of the previous era. ${ }^{19}$ The offensive against the sinecures of the white workers, which had begun inadvertently with the adoption of the cyanide process, signaled their new position. The American engineers called their war on the craft-like specialization of the white workforce "generalization". The specialties or "skills" of white workers were industrially determined and therefore vulnerable to technological change. ${ }^{20}$ Generalization was nothing less than quality control effected by the fusion of management and engineering capacities in the deep-level mines. ${ }^{2 \mathrm{I}}$

Alan Jeeves, Elaine Katz, Jeremy Krikler, Peter Richardson, JeanJacques van Helten, and Charles van Onselen have written ably about the dramatic turns at the beginning and end of this period. What remains little studied, though, is how a new generation of mining engineers, particularly the influential American cohort, supplanted the old "Randlords" in planning the industry's future. ${ }^{22}$ Where new gold mines should be opened, if they should be opened at all, and how they should be worked, were matters left largely in the hands of the engineers. What was the net effect of their new responsibilities? Who benefited, who lost, and why? ${ }^{23}$

19. See R.V. Turrell, “Review Article: 'Finance. The Governor of the Imperial Engine': Hobson and the Case of Rothschild and Rhodes", Journal of Southern African Studies, I3, (1987), pp. 430-43I; see also Dwight G. Morrow Papers, Special Collections, Robert Frost Library, Amherst College, Amherst, MA [henceforth DMP], box 30, file 28, "Morrow to Lamont, August 29th I9r6".

20. Elaine Katz has rightfully drawn attention to the efforts of underground white mineworkers to insist on the "specialized" nature of their particular jobs and the deployment of "allrounders" on a single task. She also pointed out that the miners linked their aspirations in this regard to the inherent dangers underground, such as silicosis and other occupational diseases. A significant segment of the white workers therefore refused to accept Honnold's prognosis of their capacities and liabilities. Hence the strike of May-September 1907. During the most desperate and extreme moments of the strike some of the most intransigent white workers urged Botha's Het Volk government to take control of the goldmines: See Elaine N. Katz, "The Underground Route to Mining: Afrikaners and the Witwatersrand Gold Mining Industy from 1902 to the 1907 Miners' Strike", Journal of African History, 36 (1995), pp. 471-475; see also Anon., “The Strike: Lively Proceedings", Pretoria News, 27 May 1907; Anon., "No Expatriation: Work for Workless", Sunday Times (Johannesburg), 25 August 1907.

2r. See WLHP, letter book C, "Honnold to McDermott, Wetzlar, and Oppenheimer", 17-22 February 1908.

22. The significant exceptions are Belinda Bozzoli, The Political Nature of a Ruling Class (London, I98I), and Frederick Johnstone, Class, Race and Gold (London, I976).

23. See Jeeves, Migrant Labour in South Africa's Mining Economy, pp. 61-62; Katz, "The Underground Route to Mining”, pp. 467-474; Krikler, White Rising, pp. 23-25; Richardson and Van Helten, "Development of the South African Gold Mining Industry", p. 338; Charles van Onselen, The Small Matter of A Horse: The Life of 'Nongoloza' Mathebula, 1867-1948 (Johannesburg, I984), pp. I-4. 


\section{AMERICAN ENGINEERS IN SOUTH AFRICA'S GOLD MINES}

American engineers occasionally perceived themselves as promoters of other peoples' liberty. But their espousal of the ideals of nineteenthcentury republicanism- freedom of one's own person, the right to dispose of and enjoy the fruits of one's labor, and the primacy of the rule of law over personal caprice- was often tempered by their own personal prejudices and the paradoxical perceptions they inspired in key mining executives abroad. ${ }^{24}$ Local mining executives in South Africa held American engineers in high regard from the inception of gold mining in I 886 , but they also suspected their motives and were wary of their personal tastes. Consider an excerpt from the correspondence of Lionel Phillips, the chief executive officer of the Central Mining Trust (formerly Werhner, Beit and Company before the 1899-1902 Anglo-Boer or South African War), and Fredrich Eckstein, one of the company's senior partners in I907:

As to a successor: we need a man of the first rank. If such a man is available, I would prefer an Englishman to anybody else. The American element in our mines is very strong, and it would not be bad thing to have a chief engineer of another nationality. The alternative is an American or German. It is important that the man be technically qualified and of unimpeachable character, but also that he should be a gentleman and agreeable: if has got a pleasant wife, so much the better. ${ }^{25}$

Several years earlier Hamilton Smith, one of the first American engineers to work in South Africa, took a rather different view of American engineers in relation to their colleagues from other industrial countries: "Well, in South Africa the American never lets up. He works from daylight until dark and is thinking about his job in the evening. Our European engineers want to stop at four; the Englishmen to play tennis, the Germans for their beer." 26 Smith's observations were more than a series of apparent asides about national character. They were in fact a series of assessments about how far discrete groups of engineers were willing to compel the entire workforce to conform to the pace of new machinery.

The estimable position of American engineers in South Africa derived from their seminal role in encouraging and facilitating the MacArthurForrest cyanide processing of gold ore. When first developed in the latter I 880 s, the cyanide process was one of a number of processes that promised to aid mine owners in their struggle to make the mining and processing of refractory low-grade ores profitable. ${ }^{27}$ Heenen Jennings, an American

24. C.S. Herzig, "The Handling of Colored Labor", EMJ, 2 June i906, p. I055.

25. Barlow Rand Archives (Johannesburg, South Africa), HE I 54 , "L. Phillips. Private London Letters. 1907-1909".

26. As quoted in A.R. Ledoux's "The American Mining Engineer", EMJ, 25 February 1904, p. 3 I0; Ledoux was the president of the American Institute of Mining Engineers at the time.

27. A.P. Cartwright, The Corner House: The Early History of Johannesburg (London, 1965), pp. 95-98; Kubicek, Economic Imperialism in Theory and Practice, p. 63; T. Lane Carter, "Methods 
mining engineer employed by the Corner House investment group, convinced his employers to adopt the process. Its adoption proved enormously profitable during the decade before the outbreak of the Anglo-Boer or South African War in I 899. Looking back on the prewar period in 1903 , Jennings observed:

It was necessary for the conscientious engineers who first came on the Rand to educate first themselves, then their principals [...]. The education of the engineer was far easier and more rapid than that of the principals; but in justice to the latter it must be said that the final education of the mine owner, as to the wisdom and necessity of opening his purse wide for large and improved methods of work is here greater and more complete than in any other goldfield of the world. ${ }^{28}$

The success of the cyanide process in treating low-grade ores ensured the long-term profitability of the mines. Its widespread use signaled important changes in both milling and extraction. In fact, the prewar mining operations at the outcrop or placer mines could only be sustained by more extensive chemical extraction of gold from their stockpiled tailings. By I 897, well over one-third of the annual gold output was the result of leaching tailings with cyanide. Chemical leaching and more intensive hand sorting of ore on the surface, usually by African adolescents, were techniques promoted largely by American engineers. ${ }^{29}$

Once the profit-making potential of the outcrop mines began to decline after the I 895 stock market crash, mine owners and engineers turned their attention to exploiting true deep-level mines - mines that were 5,000 feet or more ${ }^{30}$ Mines at this depth contained primarily low-grade ore. Hence the new cyanide process became a potential means of reducing working costs and of increasing the redundancy of the costly underground white workforce.

These portents were evident before the war. But during the war the mine owners chose instead to cut the monthly wage of African workers who

for Assaying Cyanide Solutions for Gold", Engineering and Mining Journal, I 5 November I902, pp. 647-648; James Gray and J.A. McLachlan, "A History of the Introduction of the MacArthur-Forrest Cyanide Process to the Witwatersrand Goldfields", Journal of the Chemical, Metallurgical and Mining Society of South Africa, June 1933, pp. 375-395.

28. Heenen Jennings, "The Witwatersrand Gold Fields", Engineering and Mining Journal, I I April 1903, p. 562 .

29. Alan Lougheed, "Discovery, Development and Diffusion of New Technology: The Cyanide Process of Gold Extraction, I887-1914”, Prometheus, 7 (1989), pp. 61-74; see also Robert L. Spude, "Cyanide and the Flood of Gold: Some Colorado Beginnings of the Cyanide Process of Gold Extraction", Essays and Monographs in Colorado History, I 2 (1991), pp. I-35; Simon Katzenellenbogen, "Cyanide and Bubbles: Patents and Technological Change in Gold and NonFerrous Metals Treatment”, in Klaus Tenfelde (ed.), Sozialgeschicte des Bergbaus im 19. Und 20. Jabrhundert (Munich, 1992), pp. 519-537; Edwin H. Messiter, "The New Kleinfontein Conveyor System", EMJ, 26 May i 906, p. 995.

30. Anon., "Africa: Transvaal [Geldenhuis Deep]", EMJ, 26 February i 898, p. 263; see also Anon., "Africa: Transvaal [Crown Deep]", EMJ, 7 May i898, p. 563. 
returned in I90I to one-half of the of the I 896 average. ${ }^{31}$ Close to 50,000 African workers refused to return to the mines. Moreover, the Rothschild merchant banks, the principal backer of prewar South African mining operations, balked at the prospect of underwriting the deep-level mines. ${ }^{32}$ Meanwhile working costs doubled under difficult postwar economic circumstances. Close to 60 per cent of working costs was absorbed by the white wage bill. ${ }^{33}$ Reducing working costs thus became an all-consuming quest for the mine owners during the immediate postwar period. ${ }^{34}$ Mine owners and engineers were faced with severe and heretofore unanticipated constraints. ${ }^{35}$

South Africa's major gold mining companies also experienced a dramatic reduction of their profit margins from outcrop or placer mines during the immediate postwar period. ${ }^{36}$ Faced with a looming financial crisis, which was precipitated by the corrosive effects of the war, falling stock prices, rising costs, and labor unrest, the mine owners once again focused most of their attention on exploiting the deep-level mines, particularly those in the

31. After spending many hours discussing the wage question with mine owners like Sir Hercules Robinson, Evans Bell concluded, "The mine-owners had, however, tried to reduce this wage, and everyone I spoke to averred that higher wages could not be paid. They, however, admitted that high dividends had been the result of low wages, which had led to the present labour difficulty. The Chamber of Mines seems at present to be angling for the importation of Chinese at rates of wages that will speedily be raised when John Chinaman grasps the situation"; see Evans Bell, Labour and Other Questions in South Africa (London, 1903), p. 32.

32. Anon., "Financing Some Deep Level Mines in the Transvaal", EMJ, I 8 October 1902, p. 5 I7; Anon., "Affairs on the Rand", EMJ, 7 March 1903, p. 358.

33. Anon. (editorial "Special Correspondence"), "The Labor Situation in the Transvaal”, EMJ, 4 May 1907, p. 868; Edward Walker, "The Centralization of Power Production on the Rand", EMJ, 4 May i 907, pp. 950-95i.

34. T. Lane Carter observed, "Of the native workers, the Zulu boys are the best. There were quite a number of them here in 1896 , but as the pay on the Rand is only a little higher than in Natal, they have practically deserted the gold fields"; see T. Lane Carter, "The Kaffir MineWorkers", EMJ, I8 February 1904, p. 281; see also Dianna Cammack, The Rand at War (Berkeley, CA [etc.], 1990), pp. 50-52; T. Lane Carter,"Mining Methods at Johannesburg”, EMJ, I 8 April I903, p. 597; see also A.M. Robeson, "Hoisting From Great Depth”, EMJ, I 3 December I902, p. 780.

35. One analyst of the "labor shortage" in South African mining framed the problem in this fashion, "Heretofore negroes have been largely employed but it now appears that the negro prefers to live off his cattle or by tilling the soil, and to forego the questionable luxuries of wearing store clothes and a top hat, and of drinking rum. He evidently does not relish the ceaseless toil in the mines under conditions which practically make him a slave of the white man, all of which would seem to indicate that after all the negro has a fair amount of common sense"; see Hiram Maxim, "The Chinese and the South African Labor Question", Fortnightly Review, March I 903 , p. 506.

36. See Van Onselen, "The World that the Mine Owners Made”, pp. I-43; see also Marks and Trapido, "Lord Milner and the South African State", pp. 55-80; G. Blainey, "Lost Causes of the Jameson Raid", Economic History Review, I 8 (1965), pp. 348-353; Thomas Pakenham, The Boer War (New York, I979), pp. I-4I; for an alternative explanation see Elaine N. Katz, "Outcrop and Deep Level Mining in South Africa before the Anglo-Boer War: Reexamining the Blainey Thesis" Economic History Review, ns 48 (1995), pp. 304-328. 
area known as the "Far East Rand". ${ }^{37}$ Unbeknownst to men like Heenen Jennings, the last lesson of the mine owners' "final education" was to prove the most difficult. Deep-level mining promised to be a lucrative but costly solution to the industry's woes..$^{8}$

As mentioned earlier, American engineers had played a central role in exploiting the deep-level mines long before the outbreak of the war. ${ }^{39}$ American engineers who came after the war, however, were caught up in the more relentless and ruthless efforts of Alfred, Lord Milner's Reconstruction administration to get the output of South Africa's gold mines back to prewar levels. ${ }^{4}$ Once the manufacturing capacity of Germany and the United States had outpaced that of Great Britain, British hegemony over international finance and trade became more directly tied to the ability of its banks to control the world's gold supply..$^{\mathrm{I}}$ Meanwhile the Transvaal, upon which Great Britain now imposed crown colony status, became the world's single largest producer of gold. ${ }^{42}$ Gold also became a means to discipline and pare down the wage bill of the industrial countries, while the entrepreneurs of the major industrial nation-states

37. See British Parliamentary Papers [henceforth BPP], CD2183 (LXII) 1904, W. Evans, "Further Correspondence Relating to Labour in the Transvaal Mines", enclosure in no. I 3 (Milner to Lyttelton, 27 June 1904); see also Richardson, Chinese Mine Labour in the Transvaal, p. 192; Richardson and Van Helten, "The Development of the South African Gold Mining Industry", pp. 330-342.

38. By 1905, 42 per cent of Rand's white employees worked underground, as compared to 66 per cent of the African workers and 8I per cent of the Chinese; see Annual Report of the Government Mining Engineer 1905-1906, Transvaal Mines Department (Pretoria, 1906), p. 2. 39. See Enid de Waal, "American Technology in South African Gold Mining before I899", Optima, 32 (1985), pp. 88-96; see also John Hays Hammond, The Autobiography of John Hays Hammond (New York, I935).

40. This dependence was perceived as a mixed blessing within the upper echelons of Werhner, Beit \& Co. and the Central Mining Trust; see Barlow Rand Archives, HE I 54, "L. Phillips. Private London Letters. 1907-I909"; see also A.P. Cartwright, Golden Age (Cape Town [etc.], 1968), pp. 16-22; Fraser and Jeeves, All That Glittered, pp. 7-20.

4I. See Robert K. Massie, Dreadnought: Britain, Germany and the Coming of the Great War (New York, I99I), pp. 2 I I-233; see also Marks and Trapido, "Lord Milner and the South African State"; Blainey, "Lost Causes of the Jameson Raid"; for an alternative explanantion see Katz, "Outcrop and Deep Level Mining in South Africa before the Anglo-Boer War", pp. 304-328.

42. While writing to his friend Jan Smuts in June 1937, Thomas Lamont, the head of Morgan Guaranty Trust, looked back over the course of American financial relations with South Africa: "Do your people realize what America's buying policy in gold has done for you? It has created a great boom in your country even though with a considerable set-back this spring [...]. Now what has this policy amounted to? It has meant that because of our under-valuation of the dollar, we have in effect in holding the price of gold at $\$ 35$ per ounce been presenting to the foreign peoples literally billions of dollars in the way of advantage. I don't mean that Britain is not buying gold. She is, but the weight of the thing has come on America." See Thomas Lamont Papers (Baker Business Library, Harvard University, Boston, MA), file 23 (2) "Correspondence: Thomas Lamont to Jan Smuts, 29th June 1937”; see also Russell Ally, Gold and Empire (Johannesburg, 1994), pp. I2-28; Brian Kennedy, A Tale of Two Mining Cities: Johannesburg and Broken Hill (Johannesburg, I984), pp. 91-92. 
searched for an antidote to the consequences of periodic economic downturn. ${ }^{43}$ While discussing the future of the Transvaal's gold mines in I904, J.H. Curle observed:

Were it not for the Rand, the gold yield of the world, which this year will reach seventy millions sterling - the high water mark of production - would show a steady decline. The increasing yield from Johannesburg, however, will not only balance the deficit elsewhere, but will insure a steady increase of the world's aggregate production for a number of years to come. ${ }^{4}$

Despite their attachment to republican ideals, most American engineers in South Africa were also committed social Darwinists and racists. They were convinced that the resuscitation of the gold mines would be doomed if adult African males were placed an equal footing with their white counterparts. Speaking before the powerful Fortnightly Club of Johannesburg on 2 I May I908, William Honnold, who by this time had become one of the most influential American engineers in the country, likened South Africa's labor and political problems to what he perceived as the "generational crisis" that accompanied the end of the Civil War and slavery in the United States:

There was now freedom of opportunity, and the restraint and compulsion of the master were replaced by the surveillance of the law and the severities of the struggle for existence [...]. It was the younger generation that was to be tried most severely by the new order [...], as regards efficiency the negroes were still far behind the white race, and, we may add, were losing rather than gaining ground [...]. In the first place, we have to recognize that different opinions as to the negro's importance as a worker may be largely due to differences between employers, as well as employments. Some employers are unqualified or tempermentally unfit to manage crude labour, [...]. These points are well understood here, but it may be of interest to recall American experience bearing on them. ${ }^{45}$

As we shall see, Honnold had held these sentiments in a cruder, more unbuttoned fashion for quite some time.

Nor did American engineers believe that the use of indentured Chinese labor would constitute a panacea for the ills of the mining industry. But once the number of Chinese workers reached a critical mass in late 1904, more engineers became convinced that they were the key to divesting the most privileged strata of white workers of control over the pace and extent

43. See Marks and Trapido, "Lord Milner and the South African State", pp. 63-71; DMP, box 44, "Morrow-Thompson Correspondence: February, I918-February, 1928"; see also Livingston, "The Social Analysis of Economic History and Theory", pp. 69-95; Martin J. Sklar, The Corporate Reconstruction of American Capitalism, I880-I9I6 (New York, I988),pp.4I9-430. 44. J.H. Curle, "The Transvaal Mines", EMJ, 3 November I904, p. 707; Schumpeter, History of Economic Analysis, pp. 1075-1076.

45. WLHP, box 2, file 6, W.L. Honnold,"The Negro in America”, 4, 2 I May 1908, Fortnightly Club, Johannesburg, South Africa. 


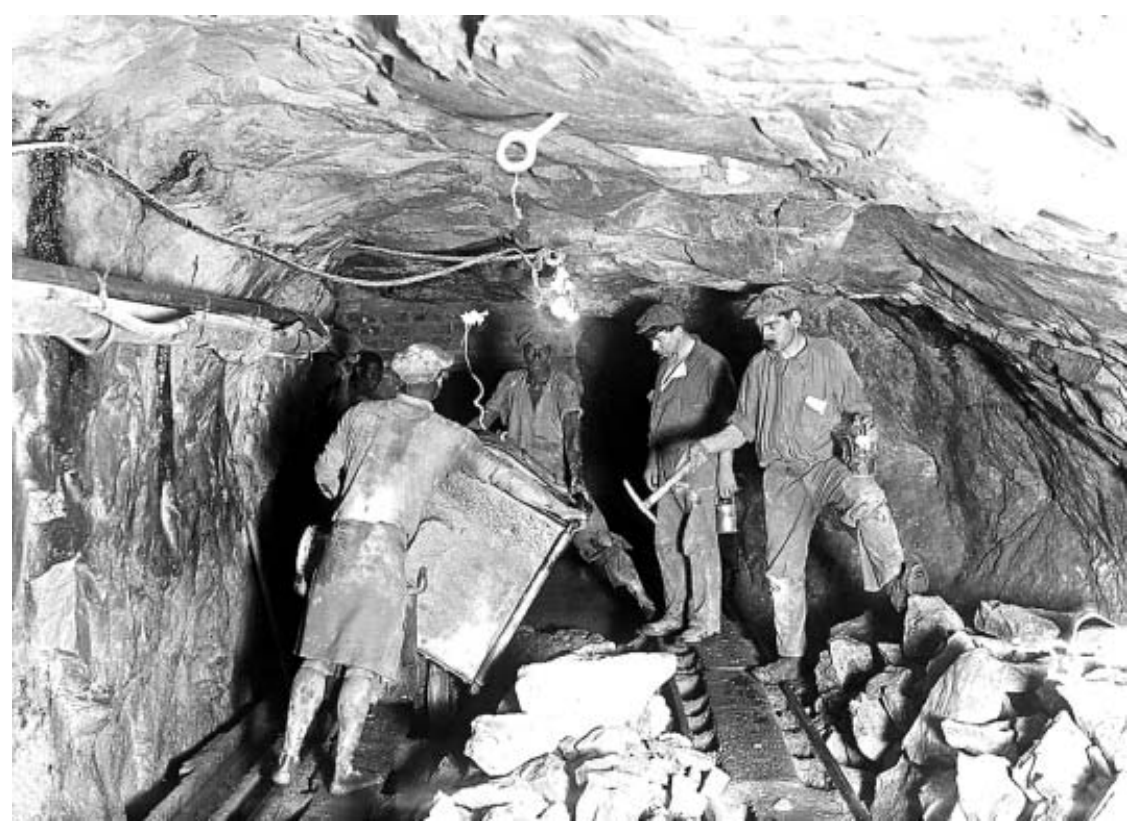

Figure I. Scene in the Rand Gold Mine, 3,000 ft underground, I9I3. This photograph subtly depicts the power and race relations in the deep-level gold mines.

New York State Archives. Used with permission.

of extraction. White drill-men, who oversaw the use of steam and rock drills by teams of unskilled African work and who were able to define themselves as contractors and "developers", proved to be particularly intractable. ${ }^{46}$ Mine owners and engineers saw them as an impediment to the exploitation of the most challenging deep-level mines, particularly those of the area known as the Far East Rand. Many did not even belong to the Transvaal Miners' Association (TMA) before the 1907 strike. Breaking their hold over the pace of industrial expansion was purely a matter of speculation before the arrival of the indentured Chinese workers. Once the Chinese arrived, however, daily quotas for drilling into the ore bearing stopes were pushed well beyond the two-foot maximum of the prewar period. ${ }^{47}$

Many of the new deep-level mines were constructed from older placer or outcrop mines. Despite increased spending on explosives and timbering, these mines still had relatively fragile infrastructures that would not allow the use of large-scale steam drills, for fear of aggravating the problem of "subsidence" or cave-ins. ${ }^{8}$ Hence many of the new deep-level mines could

46. Work and payroll schedules for African and Chinese workers, for instance, were drawn up by the "contractors": see New Kleinfontein Aı072, fo. I, Historical Collection, William Cullen Library, University of Witwatersrand, Johannesburg, South Africa.

47. J.H. Curle, "The Transvaal Mines", EMJ, 3 November I 904, p. 707.

48. Alexander Richardson (mining engineer, Treasury Gold Ltd, Cleveland, Transvaal) 
only be worked by the "ceaseless and violent" attack of the rock face by large squads of non-white workers with hammer and chisel. ${ }^{49}$ In turn, this new work routine called for white workers who supervised the squads to remain underground for longer periods of time. As a result, they were compelled to cover a larger work area and thus increase their exposure to hazardous conditions and the likelihood of accidents. Greater mortality for the entire workforce was also aggravated at this point by management's reluctance to differentiate between deep-level mines that could only be worked with hammer and chisel and those that could sustain the use of drills, even though these distinctions were common knowledge among the workforce. ${ }^{50}$

Shocking increases in mortality and accident rates were the net result of a greater concentration of inexperienced workers at the more dangerous mines. The introduction of indentured Chinese workers and the breaking of the I 907 strike of the white drill-men, then, were the beginning of a new counter-offensive that simultaneously sought to transform the bottom and top strata of the workforce. This counter-offensive, which lasted until the I 922 Rand Rebellion and general strike of the white workers, was crafted by the engineers and merely assented to by the mine owners. ${ }^{51}$

\section{LABOR SHORTAGE AND PREPARING THE GROUND FOR INDENTURED CHINESE LABOR}

By the end of 1904, mine management had conscripted over 63,000 indentured Chinese workers to mitigate the labor shortfall that they themselves created when they slashed the monthly wage of unskilled African workers. ${ }^{52}$ William Lincoln Honnold and his close collaborator,

"Subsidence in Underground Mines", EMJ, 3 August 1907, pp. I96-199; T. Lane Carter, "The Support of Excavations in the Witwatersrand Mines", EMJ, 5 May 1904, pp. 719-720.

49. See Krikler, White Rising, p. 25.

50. See "Native Grievances or Buckle Commission", Magistrate's Court Johannesburg, 28 January I914, Minutes of Evidence, "Testimony of Stanley Archibald Markham Pritchard”, pp. 2-4; see also T. Dunbar Moodie, "Maximum Average Violence: Underground Assaults on the South African Gold Mines, I913-1965", Journal of Southern African Studies, 3 I (2005), p. 556. 5 I. See WLHP, letter book A, "Honnold to Kitzinger", 6 and i 2 August 1904; WLHP, letter book C, "Honnold to Goering", 23 December 1907 and 27 January 1908; see also Parrini and Sklar, "New Thinking about the Market, I886-1904", pp. 559-569; Sklar, The Corporate Reconstruction of American Capitalism, pp. 48-5 I.

52. Peter Richardson suggests that there were approximately 47,000 indentured Chinese workers on the Rand by December 1905, but circumstances appear to suggest a larger number: See Richardson, Chinese Mine Labour in the Transvaal, pp. 197, 204; see also British Parliamentary Papers [henceforth BPP], CD 3025 "Special Committee on the Control of Chinese Labourers", enclosure 5 in no. IOI (Selbourne to Elgin, 26 May, I906); BPP, CD 3338 (LVII) 1907, "Annual Report of the Foreign Labour Department, Johannesburg, I905-1906", p. I 2; BPP, CD 3025 (LXXX) 1906, Walter L. Bagot, "Memorandum to the Special committee on the Control of Chinese Labourers"; H.C. Thomson, "Chinese Labour and Imperial Responsibility”, Contemporary Review (March 1906), p. 43 I. 


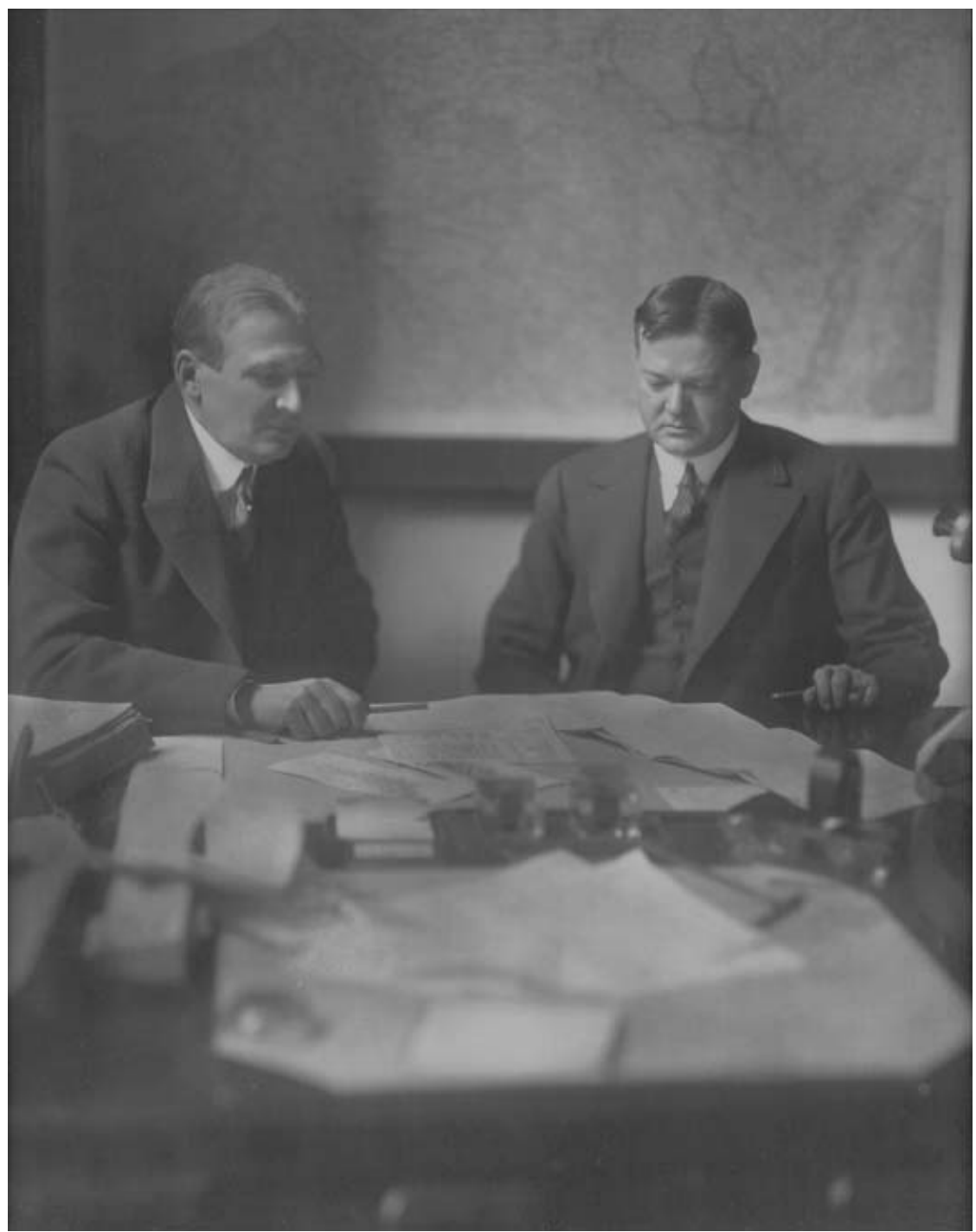

Figure 2. William Honnold and Herbert Hoover reviewing monthly production statistics at Brakpan Mine on the Far East Rand in 1905.

William Lincoln Honnold Papers, Special Collections, Honnold/Mudd Library for The Claremont Colleges. Used with permission.

Herbert Hoover, the future President of the United States who would preside over the beginning of the Great Depression, achieved some notoriety as formidable enemies of South Africa's black and white workers on the deep-level gold mines during this period. ${ }^{3}$ Honnold spent about

53. See Krikler, "The Commandos: The Army of White Labour in South Africa”, pp. 203-244; see also Norman Herd, I922: Revolt on the Rand (Johannesburg, 1966), pp. I4-19. 
thirteen years in South Africa, from 1902 to I9I5. He left just after the suppression of the failed uprising of rural Afrikaners who resented the prospect of fighting on the British side during World War I and who believed that they were literally losing ground to African peasant farmers despite the promulgation of the I9I 3 Native Land Act. ${ }^{54}$ Hoover spent much less time in South Africa, but his activities, particularly his early involvement with the Chinese Engineering and Mining Company, the primary recruiting agency for the indentured Chinese that were sent to the Transvaal, powerfully affected the context and actual deployment of the indentured Chinese laborers once they arrived in South Africa. 55

The cyanide process and indentured Chinese labor became the focal points of two distinct but related contributions to the transformation for deep-level mining in South Africa. In both instances the objectives were to humble white labor without impeding the postwar state's reassertion of white supremacy, especially in the deep-level mines, and to relocate the point of productive extraction of gold ore thousands of feet deeper in the earth. The deskilling of white labor that arose out of the use of the cyanide process was a bit of a gamble, but the decision to introduce indentured Chinese labor into the mines was only made after much deliberation. By I904, however, these contributions to the transformation of deep-level gold mining coalesced around solving the mining industry's "labor shortage" problem and lowering working costs. Honnold and Hoover's activities gave this process greater focus. Their activities contrasted sharply with the apparently transparent public proceedings of the 1903-I904 Transvaal Labor Commission. Even the dissenting minority report of the Labor Commission, which claimed that the gold mines needed far fewer workers than the majority report's 100,000 , gave no indication of where or how the requisite number of workers might be acquired. The majority report made a few oblique references to foreign sources, but no specific details followed. ${ }^{6}$ Behind the scenes, though, the real decision-making process took on a different cast.

On 30 June 1903 , more than a year before the first I, I00 Chinese recruits sailed out of the port of Hong Kong, Honnold wrote a series of letters to

54. See National Archives of South Africa, JUS no. 336, S270, "Rebellion Losses Commissions Testimony and Affadavits (see particularly the claims of Hosea Legoale, i 9 December I9I 5 , and those of Andries Jacobus de Klerk of farm Klippfontein 4IO, I6 June I9I5)"; see also Sol T. Plaatje, Native Life in South Africa (Athens, OH, I99I), pp. 366-390; Christoph Strobel, "We Are All Armed and Ready: Reactionary Insurgency Movements and the Formation of Segregated States in the American South and South Africa", North Carolina Historical Review, 80 (2003), pp. $430-452$.

55. Herbert Hoover was probably "An Occasional Correspondent" who wrote "Shipping Chinamen to South Africa" in the I 8 August 1904 issue of the EMJ.

56. Jeeves, Migrant Labour in South Africa's Mining Economy, pp. 58-59; BPP, CD 2786 (LXXX) 1905, "Further Correspondence Relating to Labour in the Transvaal Mines", enclosure no. 2, pp. 2 I and 22. 
influential engineers and bankers in the United States, Europe, and South Africa, informing them of how the decision to use indentured Chinese workers had been made. T.A. Rickard, the managing editor of the Engineering and Mining Journal and an international expert on mining costs, was Honnold's principal correspondent in the United States. Honnold's letter began by saying cheap white labor from southern or eastern Europe would have been preferable but impractical, since the strength of organized white labor on the mines made "it quite impossible to work whites and blacks together on the same task". He went on to say that, "This element is very fortified [...], although the Unions are not recognized officially, it becomes more apparent everyday that [...] we shall have much trouble from this source [...]. I feel that the white labor problem will, ultimately, cause us more trouble than the native question".57

Honnold, then, turned to indentured Chinese as the lesser of several evils that had been raised during the planning stages. Rickard and other prominent engineers in the United States had apparently urged Honnold, Hoover, and others close to the South African situation to consider the recruitment of African Americans at an earlier point. Honnold used the 30 June letter to explain why African Americans were out of the question:

These remarks are not intended for publication but more to put you in touch with the situation as it appears to position out here [...] it is quite impossible for those unfamiliar with local conditions, whether it be yourself or your readers, to see the matter in its true light. There is too much danger of saying something which will not only be misleading at home, but attract either ridicule or resentment here [...].

With regard to American niggers they would be the very worst thing that could be introduced. Aside from the fact that we require cheaper labor than they would provide, there is the much greater objection that they would tend to awake a spirit of insubordination among the ordinary natives. The nigger at home $[\ldots]$ is always looking for an opportunity to emphasize his idea of his equality with the whites, and when he comes out here, as I have had occasion to note, [he] becomes a great nuisance by reason of the distorted American ideas of liberty and equality, which he is always giving out to the niggers here [...], and therefore you can see that to introduce leaders among them with all the distorted ideas which the American nigger would be bound to bring, would be fatal..$^{8}$

Honnold had put the labor supply problem in crude but succinct terms as early as July 1902, when he had assumed the position of consulting engineer at Consolidated Mines Selection. In a 26 July 1902 letter to Herbert Hoover, then a senior engineer at Bewick, Moreing and Company, Honnold warned:

$[\ldots]$ but I can say to you $[\ldots]$ that this $[s i c]$ figures as to the available supply of

57. WLHP, box I, letter book A, 30 June 1903, "Honnold to T. A. Rickard", pp. 544-545.

58. Ibid., p. 546. 
niggers lead me to think it quite impossible to handle this situation on the old labor basis. Niggers can be used to a large extent, but I think that the sooner whites are used as workers not as lazy bones, the better. There is no reason why none of this ground can be broken as cheaply and as satisfactorily with the oneman machines used in the states as with niggers [...].59

Honnold's letter bore powerful witness to the crisis of labor and appropriate technology, and to the arbitrary application of republican ideals to the South African situation. This crisis of ideals and technology threatened to abort the potential of South Africa's deep-level mines. But it also demonstrated how far the British victory in the South African War and previous technical innovations in the mining industry had gone toward underwriting a relatively high minimum standard of living for white mineworkers. By the end of 1904 , though, that minimum was under $\operatorname{attack}^{60}$

\section{CONCEALING DEATH: THE EXPLOITATION OF THE DEEP-LEVEL MINES}

American engineers wanted to invest the prospect of offloading more risks onto the workforce with a pseudoscientific aura. ${ }^{61}$ Scientific management, the new alchemy of eager and restless men like Honnold and Hoover, appeared to be a more proactive method of cost accounting. Notwithstanding the skepticism of some mining executives, it seemed the most reasonable approach at the time. ${ }^{62}$ Toward the end of 1907, Honnold pointed to the New Kleinfontein mine as an instance of the pitfalls of a return to earlier approaches. Hundreds of the white underground workers had regained their status as subcontractors at New Kleinfontein once the indentured Chinese workers departed. Output at the mine fell by as much 4,000 fine ounces of gold:

59. See WLHP, box I, letter book A, "Honnold to Hoover, 26 July, 1902"; see also David Yudelman, The Emergence of Modern South Africa: State, Capital and the Incorporation of Organized Labor in the South African Gold Fields, 1902-1939 (Westport, CT, 1983), p. 95. 60. See WLHP, box I, letter book C, "Honnold to T.H. Leggett", 25 August 1908; see also WLHP, "Notes on Labour Reorganization on the Rand (W.L. Honnold).

6r. Thorstein Veblen captured the essence of the new circumstances: "But in the meantime two things have been happening which have deranged the regime of the corporation financier: industrial experts, chemists, mineraologists, technicians of all kinds, have been drifting into more responsible positions in the industrial system, because the system will no longer work at all without them; and on the other hand, the large financial interests on whose support the corporation financiers have been leaning have gradually come to realize that corporation finance can be best managed as a comprehensive bureaucratic routine"; see Thorstein Veblen Engineers and the Price System (New York, I92I), p. 38; see also Hirschmann, The Passions and the Interests, pp. I20-I39.

62. See WLHP, box 2, folder 8, "Honnold-Hoover Correspondence, 2 October 19I4-II November 19I4". 
Fortunately Ecksteins are able to come to the rescue, and I will contribute 39,000 ozs on Mon[day] if advisable, from the various reserves. This will still leave this group with about 75,000 oz. reserve. It is too bad this safe policy is not more generally followed [...]. From my simple-minded point of view, it seems if certain people would only abandon this for-the-time-being exhausted idea that by exaggerating the capacity of their mines, they will revive confidence and thereby create a market for their shareholdings, and, instead would reduce their individual roles to a safe basis - one that would incidentally permit building up of strong reserves. We should, without materially if at all sacrificing the support of the shareholders, gradually get into such a position as to be largely independent of outside capital. ${ }^{63}$

Herbert Hoover had entered the fray several years earlier. Never one to mince words and in the "habit of commanding" others, Hoover made a rather startling declaration to G.A. Denny who, before Honnold's rise to prominence, was the one of the principal American theoreticians of mining technique on the Rand: "Starting with an assumption of unbroken continuity to their utmost boundaries, our South African friends need little outside of compound interest tables upon which to found their finance. In the great majority of mines, however, the result of development at their lowest levels remains speculative" ${ }^{64} \mathrm{He}$ expanded on this point later in the year:

[...] you, in effect, say that the unashamed and essential American idea is that it is poor business to mine for posterity, and I assume from the context that you offer this as a criticism on my plan. The proposal I laid down will, if followed, exhaust a mine far more quickly than is common in American practice. It is my belief that it is possible to extend the development in an average mine by the depth to which the shaft can be sunk, say 350 to 450 feet per annum, $[\ldots] .{ }^{65}$

Hoover also stated that solving the problem of the ratio between the primary and secondary plant in deep-level mines was a matter of expansion rather than reference to the original installation. In the South African instance the "original installation" was almost always an older outcrop mine. His approach to milling and processing the ore turned on essentially the same approach:

63. See WLHP, letter book C, "Honnold to Julius Wetzlar, Managing Director of Consolidated Mines Selection Limited, 23 December, I907"; see also the monthly rock-breaking reports ("Cost of Breaking Rock on Quartz Winning") for the central, western, and eastern portions of the New Kleinfontein Mine from March to December 1908: see New Kleinfontein Company Limited Monthly Reports A I I (University of the Witwatersrand, Historical Collections, William Cullen Library, Johannesburg, South Africa).

64. See Herbert Hoover, "Correspondence", EMJ, 24 March I904, p. I i6; see also G.A. Denny, "The Economic Ratio of Treatment Capacity to Ore Reserves", EMJ, I 4 July 1904, pp. 53-54; Herbert C. Hoover, "The Valuation of Mines”, EMJ, i9 May i904, p. 80 I.

65. See H.C. Hoover, "Ore Reserves and Treatment Capacity”, EMJ, I 8 August I904, p. 253. 
In order to get competent comparison of the matter under differing conditions, it will be necessary to show the horse-power used on a "per ton" basis, and the cost of horse-power upon a horse-power basis, together with total hours of labor employed on a "per ton" basis, and the cost of labor per hour. ${ }^{66}$

From Hoover's vantage point reducing working costs could only be effected by speeding up depreciation schedules. ${ }^{67}$ Human beings would thus be pitted against the capacity of machinery. Machines rather than humans would become the measure of effort.

This redefinition of work in the mines called for a reduction of white contractors for sinking the vertical shaft and skilled workers at the milling and stamping works. It also prescribed a closer working relationship between the accountant, mine manager, and engineer. These innovations would have placed all creative responsibility for the work routine into the hands of the engineers, while transforming the industry's entire financial structure. ${ }^{68}$

Many deep-level mines could not be exploited with heavy machinery like steam drills because of the likelihood of subsidence or cave-ins. ${ }^{69}$ African or Chinese workers using hammer and chisel and perhaps handheld rock drills seemed the best insurance against frequent accidents. ${ }^{\circ}$ As early as I 903 , a white miner acting might have found himself supervising as many as thirty to forty Africans in the larger mines. By early I904, many of these teams were using rock drills, even though many managers thought that hand drills broke up a larger amount of waste rock in the unusually narrow work areas or stopes in South Africa's deep-level mines. ${ }^{71}$ All these minor but incremental adjustments to the work routine tended to underscore the white drill-man's conception of himself as a subcontractor, particularly in mines where the risk to life and limb increased sharply.

Cave-ins were a frequent threat in deep-level mines that had originated as

66. See H.C. Hoover, "Treatment of Sulpho-Telluride Ore”, EMJ.

67. Apart from the details of their argument, Honnold, unlike Hoover, was willing to concede that solutions to the more intractable features of deep-level mining in South Africa would take years rather than months: see WLHP, box I, letter book A (747), "Correspondence: Honnold to Kitzinger, I2 February 1904"; see also Herbert C. Hoover, "The Training of the Mining Engineer," Science, 24 November 1904, p. 719; A.M. Robeson, "Hoisting From Great Depths", $E M J$, 3 December 1902, p. 780; T.A. Rickard, "Even Methusaleh Died," EMJ, 25 April 1903, p. 658 .

68. See Elaine N. Katz, "Revisiting the Origins of the Industrial Colour Bar in the Witwatersrand Gold Mining Industry, I891-1899”, Journal of Southern African Studies, 25 (1999), pp. 73-97; see also idem, "Outcrop and Deep Level Mining in South Africa before the Anglo-Boer War”, pp. 304-328.

69. W. Fischer Wilkinson, "The Transvaal [on the Thirteenth Report of the Transvaal Chamber of Mines]", EMJ, 7 January 1904, pp. 26-28; (Alexander) Richardson, "Subsidence in Underground Mines", pp. 196-199.

70. Carter, "Mining Methods at Johannesburg", p. 597.

7r. Fischer Wilkinson, "The Transvaal”. 
outcrop mines. In many instances the roof of the work areas or stopes in the deep-level mines were supported by pillars composed of worked out ore from the original outcrop mine. The trouble was that the pillars would often collapse if they did not connect to the roof of an excavation at the proper angle. More often than not, the appropriate angle was about I 30 degrees at the bottom of the fault as opposed to the top. The likelihood of these small but deadly disasters increased on the Central Rand after the war, once more stopes were cut with machinery and more outcrop mines reworked as deeplevel projects. ${ }^{72}$ Three of the largest mines on the Rand in 1906-Cinderella Deep, Crown Mines, and East Rand Proprietary Mines- had originated as a series of smaller outcrop mines. So had Geldenhuis Deep, Rose Deep, Driefontein, and Durban Deep - mines that became notorious for their alarming number of accidents among African and white workers.

Many deep-level mines could not be opened by simply tracing the outcrop in order to cut the crucial vertical shaft. As a result, men and machines had to be hurled down an initial 600 to I,000-foot vertical shaft without the certainty of ventilation or protection from underground water. Faulty cables and winding machines for elevators or the dangerous concentration of machinery at vulnerable spots contributed to the insecurity. And of course, there was the ever-present danger of miners' phthisis due to the accumulation of rock dust and lack of ventilation. Occasionally these dangerous conditions sparked wildcat strikes like the one at Gembokfontein no. 32 near the Randfontein Estates in $1903 .{ }^{73}$

Tube mills arrived at the gold mines on the heels of the indentured Chinese workers in $1904 .{ }^{74}$ The mills concentrated chemically treated ore into a mud or sluice, and sped it to the crushing machines by means of a metal tube, thus raising the yield of gold per ton to as much as 90 per cent in some cases. Re-grinding and decantation of the mud in tubes as opposed to flat surfaces increased the amount and purity of the yield. After witnessing the most successful application of this process at the Calumet and Hecla copper mines in Houghton, Michigan, G.A. Denny claimed that higher extraction could be had by re-grinding ore just out of the earth as well as chemically treated sluices and tailings. Denny urged, "Houghton and Johannesburg [to] come together and compare notes"..$^{75}$

Once tube mills were installed, the number of mining stamps also rose to 5,555. By October 1905, there were 6,725 stamps in operation. Ironically,

72. Carter, "The Support of Excavations in the Witwatersrand Mines", pp. 719-720; G.A. Denny (Johannesburg, i r May 1903), "Mine Sampling”, EMJ, 27 June 1903, p. 96 I.

73. Anon., "Progress on the Rand", EMJ, го May 1903, p. 738; William Cullen, "Miners' Phthisis and Dust in Mines", EMJ, 25 April 1903, p. 658.

74. Anon. (G.A. Denny), "Recent Cyanide Practices on the Rand", EMJ, 24 August 1904, p. 290; E.J. Laschinger, "The Decantation Process of Slime Treatment", EMJ, 29 September 1904, pp. 503-504; Jeeves, Migrant Labour in the South African Mining Economy, pp. 60-6I.

75. Anon. (G.A. Denny), "Re-Grinding”, EMJ, 3 November 1904, pp. 699-700. 
though, the mines with greatest number of stamps, such as Knights Deep, did not have tube mills. Ore from Knights Deep was not subjected to treatment by tube mills until early 1907, when the mine management at Knights Deep and Simmer East combined their milling capacities. ${ }^{76}$ Even so, the size of a mine's physical plant was now defined by the number of tons of ore it could treat rather than the number of stamps in operation. One tube mill could crush as much ore as ten stamping machines. The previous absence of tube mills and the distance between the two work places meant that the work routines sped up dramatically in order to supply stamping machines with enough ore..$^{77}$

Still, white labor's portion of the wage bill hovered between 50 to 60 per cent of working costs. Hence the introduction of new technology and indentured Chinese labor had no immediate effect on lowering working costs, even though it did remedy the apparent shortage of unskilled labor in the mines. Moreover, Chinese were eventually placed on a piecework system. Piecework tended to underscore the position of a large percentage of the white workers as subcontractors and petty entrepreneurs, since they were responsible for the written evidence confirming the daily output of the team and whether it was meeting the monthly quota. ${ }^{78}$ If technical innovations and milling tended to be destructive of the white worker's skilled status by October 1905, the sharp increase of indentured Chinese to 45,956 or 32.2 per cent of the unskilled workforce and their concentration at the most troublesome mines tended to reinforce it. ${ }^{79}$

Mining on the Rand was fraught with tragic outcomes - particularly since working costs remained high and offloading more operating risks onto the workforce countenanced more unstable and dangerous circumstances underground. ${ }^{80}$ The lack of timbering among the shafts, work

76. Fischer Wilkinson, “The Transvaal”, pp. 80-83; Anon., “The Jumpers Gold Mining Company”, EMJ, I 2 January I907, p. 85; Anon., “Johannesburg Dec. 24”, EMJ, 26 January 1907, p. 207.

77. Fischer Wilkinson, “The Transvaal”, pp. 80-83; Jeeves, Migrant Labour in the South African Mining Economy, pp. 60-64.

78. New Kleinfontein Aı 12 , fo. I (work quotas for New Kleinfontein, Benoni, KGCA and New Kleinfontein Deeps mines), Historical Collection, William Cullen Library, University of Witwatersrand, Johannesburg, South Africa.

79. See notes 59 and $6 \mathrm{I}$ above.

80. Mine managers and inspectors of industry, many of whom were recently demobilized military officers, had special knowledge of these conditions. In November 1902, Donald Rolfe Hunt who, at the time, was serving as an inspector at the Crown Deep Mine, wrote the following lines to a former comrade of the Cape Mounted Rifles: "a Kaffir at Crown Deep who had leprosy came to the mine hospital from the compound with his feet all raw and no skin on them whatever right above his ankles. It appears the rats (which swarm in the compounds) had [...] a meal off them"; see Donald Rolfe Hunt Papers (Historical Collections, University of Witwatersrand, William Cullen Library, Johannesburg, South Africa), Ai655, ab2, 8 November 1902, "Letter to T.W. Purdy". 
areas, and hanging wall greatly increased the likelihood of fatal accidents. ${ }^{8 \mathrm{I}}$ In February 1906, for example, a horrifying accident took place at the South Rose Deep mine. ${ }^{82}$ Fifty African workers were drowned by water seeping in from the walls of the shaft they were opening. The incident was a poignant illustration of the disparity between working conditions and expert opinion. An editorial writer in the (Johannesburg) Sunday Times observed:

This is bad enough, but it is capped by the experts at the enquiry into the drowning of some half a hundred natives at the South Nourse [sic] Deep, who swore on oath that it was not customary to so fix the top of the shaft in course of sinking that surface water could not descend and drown the workmen at the bottom. $^{83}$

The dangerous working conditions that drove African workers away from many of the deep-level mines persisted, however. ${ }^{84}$ In July i 905 one observer admitted:

The Transvaal list of accidents in the mines will be an extra long one this year. The explanations are simple. Thousands of raw coolies are now at work underground [...]. New coolies do not know the dangers of treacherous hanging and in consequence quite a number are injured by falling rock. Nor are white men working underground over-careful $[\ldots] .{ }^{85}$

What the observer failed to mention was that African and Chinese workers were urged to drill directly into the "hanging" or support structures, and that this practice had become routine, once the drives in the reef shifted to an eastwest bias rather than a north-south one. The small surface area of the stopes in most of the deep-level mines also encouraged these dangerous practices in order to increase the area of extraction. These practices were more frequently the cause of accidents than the shortcomings of the workforce. ${ }^{86}$

8r. One British observer noted: "Moreover, although wages had been increased, there were other causes at work to hinder the causes of work to hinder the return of the natives on the Rand. Flogging was general, and the rate of mortality was such as to give the boldest pause. As against a mortality in our mines of 1.25 per I,000, as against a normal death-rate among the Kaffirs of I7 per I,०00, as against a mortality at the Kimberly Diamond Mines of 30 per I,, 00 , as against a mortality amongst our soldiers during the war of 40 per 1,000 , the native mortality in the Rand mines, from November 1902 to July 1903, ranged from 44.9 to 106.7 per I,000, with an average death rate of 70.6 per I,000; see Anon., "Yellow Slavery - and White", Westminster Review, I6I (May-June 1904), p. 483; see also Carter, "The Support of Excavations in the Witwatersrand Mines", pp. 719-720.

82. See Annual Report of the Government Mining Engineer, Transvaal Mines Department (Pretoria, I906), p. Is.

83. Anon., "Excuses Extraordinary," Sunday Times, Transvaal, March 4, I 906.

84. See Annual Report of the Government Mining Engineer, 1906, pp. I 5-2 I; see also DRHP, 8 November 1902, "Letter to T.W. Purdy".

85. Anon., "Johannesburg," EMJ, is July i905, p. I.

86. See WLHP, box 2, folder I, "Sundry Minutes and Papers (1904-1914)", pp. 2-6; see also Carter, "The Support of Excavations in the Witwatersrand Mines", pp. 719-720; (Alexander) 
Replacing the gigantic stationary steam drills with smaller, more mobile drills also threatened to increase the amount of time white drill-men spent underground by increasing the number of rock drills operating in a given stope from two to three. This innovation also caused the number of Africans and Chinese working in a stope to increase from a previous maximum of fourteen to as many as forty. Yet there was no complimentary increase in the number of white workers supervising drill-work. Drill-operators were threatened with greater physical danger and drillsharpeners were threatened with redundancy, once the number of portable rock drills increased. ${ }^{87}$ During the difficult period between 1904 and I907, the impact of the new challenges expressed itself in a rising number of strikes, mining disasters, and an increasingly more violent set of confrontations between white and non-white workers underground. ${ }^{88}$

\section{INDENTURED CHINESE WORKERS IN THE MINES}

Indentured Chinese workers bought precious time for the Rand's mine owners. ${ }^{89}$ The so-called "Chinese labor experiment" enabled them to temporize about the industry's long-term problems during this especially bad period. But over time Chinese workers proved even more refractory to underground work in the deep-level mines than their African counterparts. By August 1905, Chinese workers were responding in kind to the violence meted out to them by white officials and workers, even though they had been touted as mere "muscular machinery" just a year earlier..$^{\circ}$ Management's overblown assessment of its success was an important catalyst for the labor riots that swept through the larger deep-level mines of the Central and the Far East Rand between June and September I $905 .{ }^{9 \mathrm{I}}$

At the outbreak of the violence well over I,000 of the 40,000 Chinese workers on the Rand were already in prison..$^{92}$ Chinese who were

Richardson, "Subsidence in Underground Mines", pp. 196-200.

87. Fischer Wilkinson, "The Transvaal”, pp. 38-40; see also J.H. Pitchford (former manager, Randfontein Deep), "Conditions Met in South African Mining”, EMJ, 9 March 1907, pp. $467-47$ I.

88. See Annual Report of the Government Mining Engineer 1905-1906, Transvaal Mines Department, p. 22; see also Annual Report of the Government Mining Engineer 1906-1907, Transvaal Mines Department, pp. 2, 9, 10, 20, 22, 29, and Table 21; Report of the Native Grievances Inquiry, 1913-1914 (Westport, CT, I970), \$\$ 65, 92-96, 289 and 302.

89. See Richardson, Chinese Mine Labour in the Transvaal, pp. I-17.

90. See Anon., "Yellow Slavery - And White", p. 489; for accounts of some of the first assassinations of white supervisors of Chinese workers see: Archives of the Central Mining Trust (Rhodes House, Oxford University: henceforth CMT), Central Mining 22/4 "Correspondence" (1904-1905).

91. See Richardson, Chinese Mine Labour in the Transvaal, pp. I71-173.

92. Out of the 136 reported crimes between June 1905 and February 1906, 45 involved local merchants. In fact, most of the reported crimes of indentured Chinese workers were crimes against property; see BPP, CD2563, LV, 1905, "Convictions and Sentences on Chinese 
convicted of assault, refusing to work, inciting to riot, and rioting were sentenced to jail and fined as much as one-fifth of their annual wage. The added stipulation of weeks or months of "hard labour" must have seemed rather ironic to them. ${ }^{93}$ Corporal punishment for absence from work, petty theft, forgery, and malingering were commonplace. By June igos mining officials at some of the larger deep-level mines sought and received permission to try, sentence, and imprison Chinese workers on the mining sites themselves for some of the latter infractions. Mine managers and officials at the more notorious mines such as the Nourse Deep, Geldenhuis Deep, East Rand Proprietary (ERPM), and Jumpers Deep occasionally denied that corporal punishment was exercised in precisely the way that parliamentary inquiries and local newspapers claimed, but they did not deny that corporal punishment was used to punish infractions and to increase the work rate. As a result, the distinction between "light corporal punishment" and flogging all but disappeared. ${ }^{94}$

The incidence of mortality and injury also rose steadily on the mines where Chinese workers were most concentrated. A vast number of deaths and accidents resulted when inexperienced Chinese workers were forced to expose themselves to extraordinary hazards in order to meet the increased daily quota for hand drilling. The quota for underground drilling had risen from two to three feet a year after the first group of Chinese workers arrived. Quotas of sixty inches were not unknown in some of the deep-level mines that were extensions of older outcrop mines. The practice of urging workers to drill into the "hanging", given the possibility of "subsidence" or cave-ins, amounted to a recipe for disaster.95

More than 500 Chinese were killed or permanently injured in drilling accidents on the Rand between 1904 and $1910 .{ }^{96}$ The immediate impact of mortality and injury, however, was a good deal more wrenching than aggregate statistics convey - particularly when one considers that Chinese workers saw their minimum wage of 25 cents a day withdrawn once piecerates for drilling were instituted in late 1904. Moreover, mine managers often instituted piece-work well before inspectors could have a look at a

Labourers", April I905; see also BPP, $\mathrm{CD}_{3025}$, enclosure 5 in no. I01, "Special Committee on the Control of Chinese Labourers" (Selbourne to Elgin, 26 May 1906).

93. See BPP, CD 2786 (LXXX) I905, "Further Correspondence Relating to Labour in the Transvaal Mines”, enclosure no. 23 (Selborne to Lyttleton, September 30, I905).

94. See BPP, CD 2786, enclosure no. 36, Lyttelton to Selborne (24 October 1905).

95. In 1907 Alexander Richardson reviewed the instances of subsidence on the Rand that had caused mining disasters. According to Richardson, any stope cut with a dip of between 30 and 70 degrees had a greater chance of experiencing a major accident in the event of subsidence in a deep-level mine than one cut at an angle closer to 90 degrees. By Richardson's calculations, well over half of the deep-level mines on the Rand were likely to have at least one major accident a year between 1903 and I910; see (Alexander) Richardson, "Subsidence in Underground Mines", pp. 196-199.

96. See Richardson, Chinese Mine Labour in the Transvaal, p. 172. 
mine. ${ }^{97}$ Flogging and other extreme forms of punishment were regularly applied if a worker failed to meet the 36 -inch a day quota. ${ }^{9}$ Chinese and African drill-handlers often made the 36 -inch rate by starting in an abandoned hole in the stope, which, in some instances, might have contained a disused charge of dynamite. The curve of punishment and risk exposed such a worker to the prospect of an unmerciful flogging in front of the compound manager's office on the surface or being blown to bits or buried alive underground. 99

That Chinese workers responded in a violent manner to these circumstances was certainly understandable. Violent contention and corporal punishment were normative features of work underground. Between June and September I 905 Chinese workers and white supervisors at Jumpers, Nourse, and Geldenhuis Deep confronted each other in a bloody set of labor riots. In all three instances white supervisors were targeted on the surface and underground for deadly assaults, but the conflict at Nourse Deep in August I905 defined the tenor of life and work on the deep-level mines like no other incident. ${ }^{100}$

On or about I 2 August I 905 several Chinese workers exploded a charge of dynamite underneath the company store at Nourse Deep. Several days later a gang of Chinese workers was taken into custody for attacking their white supervisors while underground. Instead of being sent to Germiston on the Far East Rand to be charged in Magistrate's Court, as the I6 June i 905 Circular 9a of the Chamber of Mines stipulated, these workers were handcuffed and locked in a storage shed on the surface. ${ }^{\text {I0I }}$ Later they were

97. See BPP, CD 28 I9, enclosure no. I4, "Selborne to Lyttelton (received 9 December 1905)", p. 22.

98. Initially the Chamber of Mines instituted a blanket withdrawal of the minimum salary for Chinese workers. When it determined that such a withdrawal might, in fact, be illegal, the Chamber left the decision to use this form of censure to the discretion of individual mine managers and foremen, see BPP, CD 2786 enclosures nos 35 and 36, "Lyttelton to Selborne (2 I23 October 1905)".

99. By 1907, the number of Chinese workers injured or killed in this way was so great that the annual reports of the Government Mining Engineer began to feature a special section on the legal prosecution that accompanied such cases. Consider the first portion of the government brief in the exemplary cases of Wang Yung Shan and An Tit Tai, "The accused were Chinamen employed on the Rose Deep mine and were engaged in drilling. They had drilled to a certain depth, and refused to continue. When ordered to proceed they removed the plug from an old hole and drilled into that instead"; see Report of the Office of the Government Mining Engineer; see also Transvaal Law Reports: Reports of Cases Decided in the Supreme Court, reported by N.J. de Wet and B.A. Tindall (Grahamstown, Cape Colony, 1906), pp. 397-40г.

100. See the correspondence between officials of Jumpers Deep, Geldenhuis Deep, and the Central Mining Trust with Mr N. Nicolaisen of Germany and Mrs Charlotte Smith of Great Britain about the alleged murder of relatives by Chinese workers during the incidents of June and September 1905 in CMT 22/4, "Correspondence" (1904-1905).

IоI. On I6 June igos the Transvaal Chamber of Mines distributed circular 9a, which forbade summary punishment of Chinese workers by the official or supervisors of a given mine, stipulating that such workers should be charged and tried in the court of the nearest magistrate. 
handcuffed to the wooden beams of the storage shed, with their feet dangling six inches from the floor, and flogged with a bamboo cane. Enraged over the beatings, hundreds of Chinese workers attacked the mine's police force. W.M. Prout, the general manager of Nourse Deep, deputized and armed white supervisors and skilled workers. When the violence was not quelled, Prout called in several mounted units of the South African Constabulary. ${ }^{102}$

On 28 August 1905, the Transvaal Labor Commission and the Governor- General called upon Prout to explain the use of excessive force in punishing Chinese workers shortly after the bombing of the company store. He was also asked to explain his refusal to send Chinese workers to civilian magistrates, even after the Chamber of Mines had ordered mine managers to do so. Prout claimed that compound managers were doing little else except processing cases for the magistrates. He also claimed:

[...], owing to the light sentences given, the desired effect is not obtained, [...]. When offences are dealt with on the mine, serious cases were of rare occurrence, [...]. At present assaults on the white miners and insubordination are of almost daily occurrence, and we lose many good miners for this reason. It is quite possible that before long the miners on the Chinese mines will combine and demand that protection of some kind be provided underground; the question has already been raised. ${ }^{103}$

Chinese workers also became the targets of a generalized state of white aggression after an Afrikaner farmer, Petrus Joubert, was murdered by a group of escaped Chinese on his farm near Pretoria in July 1905. ${ }^{104}$ The "Moab Velden Tragedy", as Joubert's murder was called in the newspapers, became the catalyst for a virulent outburst of vigilantism among Afrikaner farmers and their English-speaking counterparts. ${ }^{\text {Ios }}$ The farmers organized

In general, mine officials and supervisors were opposed to the measure; see BPP, CD 28 rg. enclosure no I4, "W. M. Prout's refutation of Boland's claims in the Daily Express (23 Aug. I905)", p. 25 .

102. Ibid.

I03. Ibid.

I04. The death notice, which was filed by Joubert's father-in-law, J.W. Venter, listed the date of his murder as 16 August 1905. Armed groups of farmers had been organized in the western Transvaal and Middelburg, however, as early as June; see microfilmed New Estates and Death Notices (Sterfkinesse): Transvaal, 1905-1906, filmed at the Central Archives Depot, Pretoria, SA by the Family History Library of the Church of Jesus Christ of the Latter Day Saints, R-5 I 583 ; see also BPP, CD 2786 (in continuation of CD 240I, April 1905, and CD 2563, July 1905), "Further correspondence Relating to Labour in the Transvaal Mines, presented to both Houses of Parliament by command of His Majesty December, I905”, enclosure no. 2, p. 2 I.

I05. On 23 August 1905, an editorial in the Pretoria News laid the blame for the widespread appearance of armed groups of farmers on the disgruntled Boer military leaders and aspiring nationalist politicians in Het Volk: "To talk of prowling bands of Chinese coming to murder and maltreat the farmer at any unexpected momen [sic] is mischevious nonsense, exactly as it is 
themselves into mounted bands and scoured a large area between the foothills of the western Transvaal and the farming towns that surrounded the mines of the Far East Rand in search of fugitive Chinese workers. ${ }^{106}$ This widespread but inchoate movement became the transitional mass base of political support for Het Volk, the burgeoning Afrikaner nationalist party of the day, and for a general rearming of the Transvaal's Afrikaner farmers, many of who had fought against Great Britain during the war. ${ }^{107}$

On 5 September I905 the leadership of the white farmers' movement demanded a meeting with the appointed Legislative Council and Arthur Lyttelton, the Lieutenant-Governor. Some of the most vocal leaders were also some of the most unreconciled of the Boer military leaders such as A. Liebenberg and C.F. Beyers, as well as the apparently more rational Louis Botha, the former commandant-general of the South African Republic's army. A day later, on Wednesday, 6 September I905, they were granted an audience with the government's representatives. Botha had the final say: "I hope that Your Excellency will never allow the mining magnates, who never had the slightest sympathy for the rest of the population, to come forward as protector of the public. We want protection from the Government and not from the mines". ${ }^{108}$

\section{ENGINEERING EMPIRE: THE TRANSFORMATION OF THE WORK ROUTINE}

By the beginning of 1907 the transformation of work in the deep-level mines began to pick up speed. More work in the deep-level mines moved forward on the basis of power generated by electricity - at first haltingly and then in a series of dramatic leaps after 1909 - and a new set of ideas about the possibilities and constraints of black and white labor in the mining industry. ${ }^{109}$ The significant twist in the new arrangement was that electricity could not only pump water out of mines and air in, but it could also compel workers to spend more time underground. ${ }^{\text {Iо }}$ Electricity also

ridiculous to suggest that one farmer has been murdered by Chinese, the Boers should be armed on easier terms than exist at present. We have had many excuses put forth by thrifty Boers for obtaining arms on 'easy terms', but none more painfully flimsy than this last"; see Anon., "A Crime and a Policy", Pretoria News, 23 August I 905; see also, Anon., "Murder Near Bronkhorst Spruit," Pretoria Newes, i7 August 1905.

106. See various issues of Land en Volk, the Pretoria News, and the (Johannesburg) Sunday Times between August and November i905; see also BPP, CD 2786.

I07. Kynoch, "Your Petitioners are in Mortal Terror", pp. 543-546.

108. BPP, CD 2786 (in continuation of CD 2401, April 1905, and CD 2563, July 1905), "Further Correspondence Relating to Labour in the Transvaal Mines, presented to both Houses of the Parliament by Command of His Majesty December 1905", enclosure no. 2, pp. 2 I and 22.

ı09. See Walker, "Centralization of Power Production on the Rand", pp. 950-95 I; see also Carter, "Mining Methods at Johannesburg", p. 597.

I Iо. See T. Lane Carter, "Water in the Witwatersrand Mines", EMJ, i A August 1904, pp. 227- 
made it possible to increase dramatically the number of African or Chinese workers under a given white worker's supervision. ${ }^{\text {II }}$ Mining engineers waxed sanguine over these results; white drill-operators perceived such changes with great trepidation, even though they appeared initially to confirm their importance in the production process. However, increased periods underground translated to a greater likelihood of being trapped during accidents and cave-ins.

Underground teams were sometimes composed of workers using stationary and mobile drills. This meant that one white worker, with the assistance of several African or Chinese "boss boys", could be responsible for as many as 80 to 100 African or Chinese workers. ${ }^{\text {II }}$ A sharp tension arose therefore between the technical requirements of the mining industry and the social organization of labor in the deep-level mines. ${ }^{\text {II }}$ The gains that white workers had made in South Africa's mining industry after the I 895 financial crash were suddenly at great risk, given their more insecure position within the production process on the deep-level mines. ${ }^{\mathrm{II}} 4$

The white trade unions such as the Transvaal Miners' Association (TMA) and the Amalgamated Society of Engineers (ASE) and the racially exclusive South African Labour Party (SALP) were unable to offer a coherent alternative. Of course, there was the piecemeal plan of the SALP's most flamboyant spokesmen, F.H.P. Cresswell. Ironically Cresswell's ideas had been formed while he was a mine manager at the notorious Village Main and Durban-Roodepoort mines before the outbreak of South African War. ${ }^{\text {Is }}$ His plan bore a marked resemblance to the one developed by William Honnold and his assistant engineer, C.E. Knecht. ${ }^{116}$ Neither plan secured the living standards of white workers against possible advances by African workers. Rather, in both plans, a second tier of the white workforce was envisioned, while Africans and

228; see also Walker, "Centralization of Power Production on the Rand”, pp. 950-95 I; Kubicek, Economic Imperialism in Theory and Practice, pp. 49-50.

I I. See WLHP, box 2, folder I, "Sundry Minutes and Papers (1904-1914)", p. 6.

I I 2. See Elaine Katz, A Trade Union Aristocracy: A History of White Workers in the Transvaal and the General Strike of 1913 (Johannesburg, I976), pp. I30-I32; see also WLHP, letter book C, "Honnold to Julius Wetzlar: 6 January 1908"; WLHP, box 2, folder 2, "Notes on Labour Reorganization on the Rand (W.L. Honnold)", 2 I June 1907.

II3. See Kubicek, Economic Imperialism in Theory and Practice, pp. 49-50; see also Carter,"Mining Methods at Johannesburg"; WLHP, "Report on the Brakpan Mines by Assistant Engineer Davis" (see particularly the section entitled "Report on Stoping").

I I 4. See John Hays Hammond Papers (Sterling Library, Yale University, New Haven, CT), box 3, letter book 2, "John Hays Hammond Sr to Richard A. Parker Esq., Consulting Engineer, Marquette, Michigan USA, 29 May i 895 ".

i I s. See S.J. Truscott's assessment of Cresswell's ideas in later editions of The Witwatersrand Goldfields: Banket and Mining Practice (New York, I898), pp. I 57 and I94.

ir6. See WLHP, "Report of Assistant Engineer C.E. Knecht to Honnold (Consulting Engineer)", 30 March, I908; see also WLHP, "Notes on Labour Reorganization on the Rand (W.L. Honnold)", 2I June, I907. 
other non-whites were relegated more or less to development work. What distinguished the two plans was the degree of permanence attached to the second tier of white workers. Cresswell envisioned it as a conveyor belt to the more remunerative positions in the first tier; Honnold and Knecht envisioned the second tier as a permanent division within the white workforce. White workers and their trade unions did not rush to embrace either plan. But on the eve of the 1907 strike John Reid, an SALP representative in the Legislative Assembly warned his constituency that "the day was past when the white man could smoke his pipe and watch the Kaffirs work". ${ }^{117}$

The crude register of how workers must have perceived the new engineering practices was the sharp increase in the mortality and accident rates among white workers after I904. ${ }^{\mathrm{II} 8}$ However sharp the antagonisms among African, Chinese, and white workers became, they all had a vested interest in increasing their safety underground. ${ }^{19}$ The engineers did not. ${ }^{120}$ The 1907 strike demonstrated just how pointed these differences had become.

\section{MEN AGAINST MACHINES}

With Het Volk firmly in place by 1907, white miners assumed that Prime Minister Louis Botha would not intervene in their struggle against the mining companies. After all, in 1906, at the urging of their leadership, many white workers had voted for Botha and his proto-nationalist party. Workers who remembered his stinging rebuke of the mine owners during the I905 anti-Chinese pogrom believed that he and his Minister of Mines, $\mathrm{H}$. De Villiers, meant them no harm. When the state's presence in the 1907 strike was seconded by well over I,000 mounted police and soldiers instead of a permanently seated arbitration board, the 5,000 to 6,000 strikers were momentarily stunned. ${ }^{\mathrm{I} 2 \mathrm{I}}$

The strike began on I May I 907 among the white drill-operators at the Knights Deep mine. The majority of the white underground workers at Knights Deep were subcontractors and did not even belong to the Transvaal Miners' Association (TMA), the white drill-operators' trade union. One of the persisting ironies of the strike was that whites who were

I 17. See Anon., "Engineers at Dinner", Pretoria News, i० June 1907.

I 18. See Katz, "The Underground Route to Mining", pp. 467-489.

I 19. See graphs I and 2 on p. I 3 and tables 4 and 5 after p. 26 of the Annual Report of the Government Mining Engineer, Transvaal Mines Department (Pretoria, 1904).

I 20. See WLHP, box 2, folder 2, Report of the assistant engineer C.E. Knecht to Honnold (Consulting Engineer, Brakpan Mines), 30 March, 1908, "Re Stoping on the Rand"; see also WLHP, box 2, folder 2, 2 I June 1907, "Notes on Labour Organization on the Rand".

I2 r. Anon., "The Strike: Lively Proceedings"; Anon., "The Strike: A Broken Reed", Pretoria Nerws, I 8 May 1907; Anon., "The Strike: As Told in Delagoa," Pretoria Nerws, 23 May 1907. 
recognized as subcontractors and who drew a wage of somewhere between 360 and 500 dollars a month made up a large portion of the strikers. ${ }^{\text {I22 }}$ By the end of the week over 3,000 men had gone on strike. Mine managers deemed the strike "inevitable" and talked expansively about the post-strike labor situation:

What will happen is probably this: Each rock drill will be run by a white man, receiving a small wage, from \$2 to \$2.50 per day, assisted by a Kafir. About ten or a dozen of these machines will be superintended by a skilled miner, receiving a salary of about \$r68 per month. In the hand stopes it seems highly probable that white men will actually use the hammer, and here the Kafir will be used as in the past. One white miner, however, will be responsible for a larger number of native drillers than in the past! The white, probably Dutchmen [sic], will be used to a certain extent on tramming. ${ }^{\mathrm{I} 23}$

The labor situation at Knights Deep was the starkest expression of the disjuncture between the social organization of labor in the deep-level mines and the relentless application of the new technology. Toward the end of I 906, Knights Deep shared 400 stamping machines and 3 tube mills with the Simmer East mine. Even though the mill housed the largest concentration of the Rand's 7,500 machines, most of the mill's equipment was fairly removed from Knights Deep. By September 1906 the stamping machines at Knights Deep were processing almost 8 tons of ore every 24 hours, but the distance of most of the stamps from the tube mills meant that the pressure to supply the stamping machines with ore was absorbed largely by human labor rather than machines. ${ }^{\mathrm{I} 24}$ The demand that each white worker supervise 3 drills gave a focus to this more discursive means of increasing the workrate. It was not a situation that could last forever.

The 1907 strike of the white underground workers was part of a larger, more protracted contest that pitted the engineers and the new technology in the form of tube mills, Robins conveying belts for hand sorting, and the newer, more portable drills against the tactical power of various segments of the white workforce. In 1907 it was the turn of the drill-operators. Later, during the strikes of 1913 and 1922, the engine drivers and charge men took up the contest. The I 907 strike failed, but its failure assisted in drawing the battle lines for the later definitive struggles over how the deeplevel mines were to be exploited and to whom they belonged. ${ }^{\mathrm{I} 5}$ The white

I22. Anon (Correspondence), "Johannesburg - May I3", EMJ, is June 1907, p. ir64; Anon. (Correspondence), "Johannnesburg - May 27", EMJ, 29 June 1907, p. 258; Pitchford, "Conditions Met in South African Mining", p. 467.

I23. See Special Correspondence, "Labor Problem in the Transvaal", EMJ, io August 1907, p. 249.

I 24. See Fischer Wilkinson, "The Transvaal”, p. 39; Anon., "Johannesburg Dec. 24”, p. 207; see also Pitchford, "Conditions Met in South African Mining", p. 469.

I25. See Bozzoli, The Political Nature of a Ruling Class, pp. 177-178; see also Herd, 1922: The Revolt on the Rand, pp. 27-28 and ro9-121. 
workers' final defeat was not a given; but throughout the strikes of 1907 , I9I3, and I922, they consistently failed to grasp the scope of the struggle, while ignoring the demands of African and Chinese workers in their negotiations with mining houses. Nor was there any practical unity among white workers in the various trades until the final convulsive and insurrectionary struggle of $1922 .{ }^{126}$

On 2 I May 1907, mounted army troops were deployed to assist the regular police units during the strike. Botha had just returned from Great Britain and there was some confusion about whether he, De Villiers, Lord Selborne, the Governor-General of the Transvaal, or some combination thereof had requested the troops. ${ }^{27}$ But once Botha returned, all the leading newspapers and members of his cabinet urged him to invoke the Peace Preservation Ordinance of 1902. The "law and order" ordinance, as it was commonly known, enabled the head of government to suspend habeas corpus for up to $2 \mathrm{I}$ days and to define broadly treason and sedition. ${ }^{128}$ It had only been used once before - during Milner's campaign to confiscate all the rifles in the hands of former African combatants after the conclusion of the South African War. ${ }^{\text {I29 }}$ Its potential use in 1907 appeared to confirm the greatest fear of the striking white workers: that the state and the mining houses intended to deal with them in much the same manner that they dealt with Africans and Chinese. ${ }^{130}$

By the end of May the success of the strike turned on the support of the engine drivers and blacksmiths. The engine drivers were deeply divided. Those at Geldenhuis Deep and Jumpers Deep were extremely reluctant to strike; those at Nourse Deep and South Rose Deep less so. Many of the engine drivers' assistants, the banksmen, and onsetters at the latter mines were African or Chinese "boss boys". ${ }^{131}$ But at Van Ryn, Modderfontein, and New Kleinfontein, where armed white workers had taken an active role in suppressing or containing the Chinese workers two years before, engine drivers adamantly "refused to haul scabs". ${ }^{132}$ Among the engine drivers who worked on mines where Chinese protests had been quite sharp

I26. See ibid., pp. 28-47; see also Krikler, "The Commandos: The Army of White Labour in South Africa", pp. $205-244$.

I 27. Anon., "The Strike: Troops on the Rand", Pretoria News, 23 May I907; see also Anon. (editorial), "The Preservation of Peace", Pretoria News, 24 May I 907.

I28. Anon., "The Preservation of Peace"; see also DRHP, Ar655 (Personal Correspondence), "Hunt to T.W. Purdy, Department of Native Affairs", 22 October 1902.

I 29. Ibid.

I 30. Anon., "The Strike: Withdrawal of Infantry", Pretoria News, 8 June 1907; see also Anon., "On the Square: The Bootless Ultimatum", Sunday Times, 7 July 1907.

I 3 I. Anon., "The Strike: Lively Proceedings"; see also Anon. (Correspondence), "Johannesburg - May i3", p. i 64; Pitchford, "Conditions Met in South African Mining", p. 469; "Homo", "Underground: The Miner's Daily Grind", Sunday Times, 22 September 1907.

I32. Anon., "The Strike: Lively Proceedings"; see also "Homo", "Underground: How Accidents Happen", Sunday Times, 29 September 1907. 
and where the state intervened with a combination of concessions and armed force, few thought of joining the strike; those who worked on mines where white workers had participated in the suppression of Chinese protests were much more inclined to support the strike.

On 28 May 1907, under the sponsorship of their trade union, the Association of Engineers (ASE), the engine drivers voted either to join the strike or remain at work. When the majority of the engine drivers voted not to strike, the strikers began to assume a more defensive posture. "Red flags, red rosettes, and emblems of American freedom (paper or metal lapel pins of the American flag)" were still widely displayed during the huge demonstrations that the striking workers organized in Johannesburg and in the Far East Rand towns of Benoni and Boksburg between the end of May and 4 July. By July, however, the most important slogan of the strikers became "Defense not Defiance". ${ }^{133}$

The leaders of the strike continued to express reservations about the prospect of white workers supervising three drills, but they maintained that even this measure was subject to negotiation if the mine-owners conceded an eight-hour day and greater compensation for accidents to white workers. ${ }^{\mathrm{I}}{ }^{34}$ White workers realized belatedly that the principal source of danger in the deep-level mines was no longer the means used to open them but the structural conditions that obtained during working day. ${ }^{135}$ As a result, many of their spokesmen maintained that the mine owners and the Chamber of Mines had "egged them on" to striking. ${ }^{136}$

By the end of July 1907, the strikers were clearly on the defensive: the vote in the Association of Engineers (ASE) had gone against them; veteran drill-operators were returning to mines like Jumpers Deep or hiring themselves out at the newer deep-level mines under assumed names; and unemployed Afrikaners were either signing on at the mines affected by the strike or demanding that the Transvaal Miners' Association (TMA) give them "financial assistance for having resisted becoming scabs". Botha's government could now conveniently postpone talks with the strike's leaders, while stepping up the armed repression of the strike. ${ }^{137}$

By August the strike movement had virtually collapsed. There was a temporary resurgence of mass action at the end of August, as the

I33. Anon., "The Strike: The Great Mass Meeting”, Pretoria News, 27 May i 907; see also Anon., "On the Square", Sunday Times, 7 July 1907.

I 34. See G.E. Wolcott, "Stoping with the Air-hammer Drill”, EMJ, 20 July 1907, pp. I I7-i i 8; see also Anon., "No Expatriation: Work for Workless"; Anon., "Who's for Home: Mines and Repatriation", Sunday Times, I 8 August 1907.

I35. See Katz, "The Underground Route to Mining”, pp. 470-47I.

I36. Anon., "Who's for Home: Mines and Repatriation"; see also Anon (editorial), "The Witwatersrand Miners' Strike," EMJ, July 20, 1907, I 26

I 37. Anon. (editorial), "The Sands in the Glass", Pretoria News, 3 June I907; Anon., "The Strike: Interview With The Minister of Mines", Pretoria News, 3 June 1907; Anon., "The Strike", Pretoria News, 4 June 1907. 
government, in collusion with the Chamber of Mines, prepared to replace many English-speaking white workers with less experienced Afrikaners. But the demonstrations, most of which took place in Johannesburg's white working-class enclaves of Jeppestown and Fordsburg, and picket lines were rearguard measures, even though one journalist claimed that "The Main Reef-road and the neighborhood of the mines had never known such a continuous appearance of life." ${ }^{38}$ On 24 August 1907, however, the manager at Robinson Deep noted that the mine was "shorthanded, but that the amount of rock broken was greater than ever". ${ }^{139}$ The breaking of the I 907 strike appeared to justify the practices stipulated by Honnold and the American engineers, for virtually none of the stamping mills ceased operations during the strike. ${ }^{\mathrm{I}}{ }^{\circ}$ The new practices did initiate the undermining of white workers as subcontractors that would continue until the close of the First World War. Honnold was cautiously optimistic about the outcome of the strike in most of his subsequent correspondence. On 23 December 1907 he observed,

Fortunately the strike of the white workers came along and brought a reduction in costs which the most optimistic did not expect so soon, and fortunately also, the deep-level outlook assumed a less doleful tenor [...]. The change as you of course recognize is more in the nature of a check than a correction. ${ }^{\mathrm{I} 4 \mathrm{I}}$

\section{CONCLUSION}

There were occasional dissonant and cacophonous voices that contested the "progressive" nature of the particular pattern of industrialization and state intervention the mine owners and engineers sought. Many of the defeated Boer generals supplied such voices during the moral panic among the white population that followed the Chinese labor riots of late 1904 and the "Moab Velden Tragedy". Occasionally middle-class Africans also sought to give voice to what they believed were the aspirations of African industrial workers. Consider the closing lines of a 1904 editorial in the Zulu language weekly, Ipepa lo Hlanga:

The position of the Rand at the present time with regard to natives and professions leads one to think that in the near future it shall become necessary for the black races to act independently, which will mean competition against if not

138. Between 25 August and is September 1907, the Sunday Times delivered a blow-by-blow account of the demonstrations in white working-class neighborhoods such as Fordsburg and Jeppestown and mini-strikes at some of the mines that aimed to prevent the repatriations.

I39. Anon., "The Miner's Lot", Sunday Times, 25 August 1907.

I40. See WLHP, letter book C, "Honnold to Goering, 23 December, I907".

I4I. Ibid. 
opposition to white interests. We shall then experience the same conditions as in the [United] States [...]..$^{12}$

These voices were often muted, however, by the efforts of the state, the Chamber of Mines, the various investment groups, and, most immediately, the new generation of mining engineers. The engineers sought to obfuscate mortality and corporal punishment as aspects of the social costs associated with the exploitation of the deep-level mines. They also sought to give the tragic loss of life a more neutral moral character by describing it as "wastage". Africans, indentured Chinese workers, debt-ridden white farmers, and unsuspecting white workers paid a disproportionate portion of the bill with life and limb, while attempting to make themselves heard over the din of the new machinery.

The problem for historians is that there is no way of accounting for these dissonant voices - or the lost alternatives that the engineers plowed under with jerry-built statistics about death and maiming - by simply reconstructing the secular trend of the mining industry's achievements. ${ }^{\text {I }}{ }^{3}$ Honnold and Hoover understood this problem well - perhaps too well. In the best of all possible worlds Honnold and Hoover might have recalled the words of Abraham Lincoln to frame their South African experience: "The American public has always submitted patiently to whatever inequality there seemed to be as a matter of necessity, while public politics made steady progress toward the practical equality of all men." "44 But the length of the "while" in the South African case was much longer than all the careers of the American engineers who assisted in transforming the nature of work in the deep-level mines. Business organization in South Africa became less charitable as its scale of operations increased during the 1906-1908 Depression, even though the full implications of its transformation would not be made clear until the promulgation of the infamous Mines and Works Act, the Masters and Servants Act, and the Native Land Act by the Union government between I9II and I9I3. ${ }^{\text {I45 }}$

Even though segregation in South Africa was eventually transformed into a more monstrous form of social engineering, the struggles of people who worked with their hands frustrated this transformation for much of the first half of the twentieth century. Historians would do well to listen closely to men such as William Honnold and Herbert Hoover, if only to understand how the powerful often contradicted the ideals they claimed to

142. John Dube[?], "Natives and Professions", Ipepa lo Hlanga, 26 February 1904, p. 3.

I43. See Richardson and Van Helten, "The Development of the South African Gold Mining Industry", pp. 330-342; see also JGGP, Air 34, "Correspondence: I 906 and I907".

I44. Quoted in David Brion Davis, "American Equality and Foreign Revolutions", Journal of American History, 76 (1989), pp. 746-747.

145. See Yudelman, The Emergence of Modern South Africa, p. 27. 
hold dear while pursuing objectives that dehumanized the generality of working people. They might want to take their cues from Abraham Lincoln, however, who when it mattered most chose to act in manner that subdued his immediate personal interests. 